DOI: $10.15393 /$ j9.art.2019.6141

УДК 821.161.1

Татьяна Федоровна Волкова

(Сыктывкар, Российская Федерация)

volkovatf777@gmail.com

\title{
Сюжетная организация «Казанской истории»
}

Аннотация. В статье проанализирована сюжетная организация первой части «Казанской истории» (главы 1-57) - выдающегося памятника древнерусской литературы середины XVI в. Выявлен единый принцип сюжетного повествования во всем тексте этого произведения. Это подчиненность трех сюжетных линий - «война», «мир», «Божественный промысел» - трем главным идеям «Казанской истории»: идее исторической справедливости присоединения Казанского царства к Руси, идее невиновности Ивана Грозного в пролитии русской и казанской крови во время взятия Казани и идее свершения «великим князем московским» «боговодимого» подвига - взятия Казани в 1552 г. На примере ряда глав первой части «Казанской истории» показано, как выбранный автором принцип сюжетного повествования - рассказ об измене казанцев, месть за нанесенную русским правителям обиду - проявляет себя в конкретном художественном материале и как он трансформируется во второй части «Казанской истории» - повествовании об осаде и взятии Казани Иваном Грозным в 1552 г.

Ключевые слова: древнерусская литература, «Казанская история», сюжет, нарратология, историческая беллетристика

Об авторе: Волкова Татьяна Федоровна - доктор филологических наук, доцент, профессор кафедры русской филологии, Сыктывкарский государственный университет им. Питирима Сорокина (167001, Российская Федерация, г. Сыктывкар, Октябрьский проспект, 55)

Дата поступления: 11.03 .2019

Дата публикации: 09.09.2019

Для цитирования: Волкова Т. Ф. Сюжетная организация «Казанской истории» // Проблемы исторической поэтики. - 2019. - Т. 17. - № 3. C. 7-24. DOI: 10.15393/j9.art.2019.6141

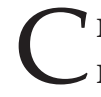

южет как система событий, выстроенная писателем в произведении, является одной из основных характеристик степени нарративности эпического произведения. В XX в., с усложнением повествовательной структуры литературных произведений, когда уже можно говорить «о развитом сюжетном (C) Т. Ф. Волкова, 2019 
повествовательном языке, в котором кумулятивные, циклические, хронологические и другие схемы и их контаминации составили ансамбль структур» [Бальбуров, 2001: 33], активизировались и теоретики литературы, работающие в сфере сюжетологии. В работе В. Шмида, профессора славистики, директора Интердисциплинарного центра нарратологии в Гамбурге, представлен исторический обзор основных концепций литературоведов XX в., по-разному рассматривающих и определяющих два основных понятия сюжетологии - фабулу и сюжет [Шмид: 138-155]. С начала XXI в. активным центром нарратологических исследований стал Институт филологии Сибирского отделения РАН, ведущий работу по составлению «Словаря сюжетов и мотивов» ${ }^{1}$ и выпускающий сборники статей по вопросам сюжетологии и смежных аспектов нарратологии ${ }^{2}$ Целый ряд статей, рассматривающих категорию мотива на разном литературном материале, появился в научном журнале «Проблемы исторической поэтики», выпускаемом Петрозаводским государственным университетом под редакцией В. Н. Захарова.

К сожалению, изыскания теоретиков относительно сущности литературного сюжета базировались в основном на литературе Нового времени и почти не касались литературы средневековой. «Разделение ветвей изучения древнерусской книжности и нововременной беллетристики, - пишет современный исследователь нарративности В. И. Тюпа, - произошло в первые десятилетия ХХ в., когда в полемиках русских формалистов и их оппонентов сформировалась эстетическая спецификация литературы как предмета научного знания» [Тюпа: 13]. Исследователь объясняет трудности нарратологического подхода к средневековым произведениям тем, что «само порождение этих текстов не было деятельностью эстетической, чем стала впоследствии практика художественного письма» [Тюпа: 13]. Это утверждение представляется нам достаточно спорным, но оно обращает внимание на специфику средневекового повествования.

В настоящее время существует лишь одна коллективная монография, в которой прослеживается постепенное развитие беллетристического начала в разных жанрах древнерусской 
литературы от памятников Киевской Руси до произведений «переходного» XVII в. Это «Истоки русской беллетристики» книга, подготовленная коллективом Отдела древнерусской литературы Пушкинского Дома (ИРЛИ РАН) в 1970 г. [Истоки русской беллетристики]. Однако некоторые произведения в указанной монографии остались недостаточно охарактеризованными. К их числу относятся «зрелые» воинские повести $\mathrm{XV}$ в. «Сказание о Мамаевом побоище» и «Повесть о взятии Царьграда турками в 1453 г.», а также продолжившая в XVI в. развитие этого жанра «Казанская история» (далее - КИ), использовавшая все художественные завоевания предшествующих периодов древнерусской литературы как в жанровом, стилистическом, так и в сюжетном отношениях.

В настоящее время «Казанская история» достаточно хорошо исследована с точки зрения истории ее текста [Дубровина, 1989, 2000], источников [Орлов], [Моисеева, 1955], вопросов поэтики [Волкова, 1987, 1989], [Трофимова], личности автора [Моисеева, 1953]. Предпринимались попытки охарактеризовать и сюжет повести. Г. 3. Кунцевич впервые поставил вопрос о наличии в КИ единого сюжета, указав на стремление автора связывать отдельные фрагменты своего повествования внутренними мотивировками [Кунцевич: 515]. Ряд интересных наблюдений об особенностях беллетристики XVI в. и использовании ее приемов в КИ содержится в разделе «Истоков русской беллетристики», написанном Я. С. Лурье [Лурье]. Исследователь отмечает факт широкого проникновения в историческое повествование XVI в. сознательного вымысла, имевшего не только публицистическое, но и чисто художественное значение, отмечает законченность сюжетной формы во многих летописных рассказах и постоянное использование в них выразительных художественных деталей, «оживляющих» повествование. Однако, определяя значение достижений беллетристики XVI в. для дальнейшего развития русской литературы, Лурье приходит к выводу о том, что авторы этого времени, в том числе и автор КИ, не внесли ничего нового в развитие сюжетного повествования. Присущая историческим произведениям XVI в. «занимательность», по его мнению, проявлялась лишь на уровне фабулы и не затрагивала сюжет. 
В результате сюжетные сцены в КИ являются, по выражению Лурье, «чужеродным явлением», не вытекают из авторской «концепции действительности» и не являются необходимыми с точки зрения общей структуры этого памятника. Чрезвычайно мало, по мнению Лурье, зависело от логики сюжета и поведение героев КИ [Лурье: 435].

Этот вывод ученого не подтвердился нашим исследованием сюжета второй части КИ (главы 58-85-я), содержащей локальный, имеющий свою внутреннюю композицию сюжет, в котором с наибольшей отчетливостью проявились черты отличия КИ от других рассказов современников о казанских событиях 1552 г. [Волкова, 1985]. Эта часть КИ представляет собой законченную в сюжетном отношении повесть, хотя она не выделена в тексте соответствующим заголовком. Первая часть КИ (главы 1-57) описывает события до похода Ивана Грозного на Казань в 1552 г. Она представляет собой рассказ о трехсотлетней истории русско-татарских отношений, предваряемый небольшим введением, в котором автор повествует о себе, затем (в главе 1) - о начале Казанского царства и о том, что произошло через 20 лет после Батыева нашествия: о приходе в разрушенный Батыем Владимир из Великого Новгорода князя Ярослава Всеволодовича, начавшего «обновлять» город Владимир и платить дань Золотой Орде (глава 2). Эта глава оканчивается словами, которые обозначают длительный период русской истории, перенося действие уже в Московскую Русь:

«Бысть же злогордая та и великая власть варварьская над Рускою землею от Батыева времени по царство тоя Златыя Орды царя Ахмата <...> и по благочестиваго великаго князя Иоанна Васильевича Московскаго...»².

Началу царствования Ивана III посвящена следующая, 3-я глава $К И$, рассказывающая о «взятии» им Великого Новгорода и потере новгородцами былой независимости. Последующие главы рисуют московско-казанские отношения при Иване III и его преемниках вплоть до Ивана IV. В главе 27 повествуется о первом походе на Казань Ивана Грозного в 1550 г., а в последующих главах - о событиях в Казани 
и Москве до подготовки Ивана Грозного к новому казанскому походу (главы 49-57). Вторая часть $К И$, рассказывающая уже непосредственно о самом походе 1552 г. и осаде и взятии Казани войсками Ивана Грозного, начинается с главы 58; эта часть имеет сложно организованный сюжет, который исследовался нами ранее (см.: [Волкова, 1983a, 1985]).

Однако первая часть КИ до сих пор не исследована в плане организации ее сюжета, что и определило наше новое обращение к этому произведению, во многом подготовившему переход древнерусской литературы к литературе Нового времени ${ }^{4}$. Наблюдения над сюжетом второй части КИ позволяют проверить, прослеживается ли в первой ее части тот же принцип сюжетного повествования, который был выявлен нами ранее.

Одной из основных особенностей организации повествования второй части КИ является наличие трех сюжетных линий, которые как бы накладываются друг на друга: одна «война» - описывает военные действия, предшествовавшие взятию Казани, другая - «мир» - рисует попытки Грозного заключить мир с казанцами и заставить их без кровопролития сдать город, третья — «Божественный промысел» - освещает все события похода на Казань 1552 г. как исполнение божественной воли. Две из этих линий («война» и «Божественный промысел») были освоены историческим повествованием предшествующего периода в «зрелых» воинских повестях «Сказании о Мамаевом побоище» и «Повести о взятии Царьграда турками» [Волкова, 1989: 28-76]. КИ добавила к ним и линию «мира», которая играет в сюжете второй части исключительно важную роль.

Другая особенность сюжетной организации состоит в том, что весь ход событий в последних 50-ти главах КИ служит раскрытию трех центральных идей повести. Первая утверждает историческую справедливость присоединения Казанского ханства к Руси, так как земли, на которых оно находилось, по концепции автора, являются исконно русскими землями; вторая призвана показать, что взятие Казани в 1552 г. - «богодухновенный» подвиг Ивана Грозного, а сам он - избранник Божий, которому уготовано свыше стать покорителем «гордой» 
Казани; третья - идея невиновности великого князя московского в казанском кровопролитии. Все три названные идеи раскрываются в локальном сюжете повести о взятии Казани Иваном Грозным умелым чередованием трех сюжетных линий, композиционными перестановками, выявляемыми при сопоставлении рассказа КИ о событиях 1552 г. с повествованием о них в непосредственных источниках КИ - Летописце начала царства и Троицком сочинении о взятии Казани [Волкова, 1983a, 1983b].

Все три идеи, раскрывающие идейно-художественный замысел автора КИ, легко обнаруживаются и в первой части. Она начинается с введения, рассказывающего о судьбе автора, многолетнего пленника в Казани, и о поставленной им задаче - создать «красную» и «новую» повесть, в которой он наметил «изъявити разумно» о начале Казанского царства и о «бывшихъ великих побъдахъ его» над «державными московскими». Рассказав о конечной победе над «злогордой» Казанью, он хочет уберечь «от скорби» русских воинов, настрадавшихся в военных походах, а простым людям дать повод «возвеселиться» и прославить Бога, уразумев «все дивная его чюдеса и великие милости», которые он посылает «вьрнымъ рабомъ своим» (300). Этими непосредственно обращенными к читателям словами автор $К И$, предваряя свой длинный рассказ, обращает их внимание и на свое новаторство в области стиля (его повесть будет написана по-новому, подругому, не так, как писалось до этого в летописях и воинских повестях), и на автобиографический аспект повествования (его рассказу можно доверять, так как он знает описываемое взятие Казани не понаслышке, а как его очевидец), и на провиденциальный аспект дальнейшего изложения исторических событий (читатель должен увидеть в ходе описываемых событий Божий промысел и прославить «великаго Бога»). Все эти авторские установки начинают реализовываться в последующих главах.

Основная часть повествования начинается, в соответствии с изложенными во введении задачами, рассказом о «начале» Казанского царства (глава 1), играющим в сюжете КИ роль 
пролога. И первые же строки этой главы передают историческую концепцию автора: «Бысть убо от начала Руския земли <...> все то едина Руская земля, идъже стоитъ нынъ град Казань...» (300). Все дальнейшее изложение русско-казанских отношений читатель должен воспринимать в контексте этого утверждения. Следующие две главы (2-я и 3-я), рассказывающие о событиях в правление великих князей Ярослава Всеволодовича Владимирского и Ивана Васильевича Московского, также выполняют функцию пролога и подводят читателя к непосредственному повествованию о русско-казанских отношениях, которые начинаются именно с правления Ивана III (глава 4).

Показательно, что рассказу о первом контакте казанцев с московским великим князем в КИ предшествует глава, в которой впервые начинает звучать мысль, организующая все последующее повествование КИ: все военные действия правителей Московской Руси есть ответ на предательство как русских князей - правителей других княжеств, - так и врагов Руси - казанцев, которые на протяжении всех периодов русско-казанских отношений первыми искали мира с московскими великими князьями, а потом нарушали договор, заключенный с ними, изменяли им, расправлялись с московскими ставленниками на казанском престоле, чем вызывали оправданные ответные военные действия Москвы.

Этот сюжетный прием - изображение сначала измены казанцев, а затем ответа на нее русских правителей, - ставший устойчивым на протяжении всего повествования $К И$, впервые обнаруживает себя в главе 3-й, рассказывающей о взятии Великого Новгорода Иваном III. Уже в этой главе в повествование вводится сюжетная линия «Божественного промысла». Рассказывая о том, при каких обстоятельствах новгородцы единственные оказались не завоеванными Батыем, автор замечает: «...и дошед бо онъ за сто верстъ до Нова града и заступлениемъ премудрости Божии обратися вспять» (курсив мой. - T. B.) (306). Вмешательством Бога, наказавшего новгородцев за то, что они «возгордЂшася», так как «ничтоже скорбных» «не прияша» от Батыя, и вдобавок к тому взяли себе в правители «держащаго латынскую въру короля литовскаго», 
объясняется и скрытая причина потери Новгородом своей независимости. Но параллельно с этим автор рисует и внешние, исторические причины гибели Новгорода, впервые обозначая устойчивую сюжетную связь «измена» - «наказание»: новгородцы, «забывше своихъ великихъ князей владимирских, презрђша и преобидъша, и ни во что же вмъниша» (306), «мало» и «плохо» помогали великому князю да еще и призвали к себе на княжение иноверца - литовского короля. Это и послужило, по сюжету КИ, причиной расправы с новгородцами великого князя Ивана Васильевича, которому «покори Богъ под работное его иго крбпкия и жестосердыя люди новъгородския» (306). Так же исторически и провиденциально автор КИ будет оправдывать и поведение великих князей Московских в их отношениях с казанцами.

По своей повествовательной структуре первая часть КИ значительно отличается от второй. Если в последних 50-ти главах описана длительная, но протекающая в один локальный отрезок времени осада Казани, то в первой части события развиваются на протяжении большого исторического периода - со времени нашествия на Русь хана Батыя до середины XVI в. Этот значительный исторический и легендарный материал делает движение событий в первой части КИ не сразу заметным, затрудняя выявление сюжетной организации повествования. Однако целенаправленный анализ текста позволяет и в этой части КИ обнаружить некий сюжетный алгоритм, имеющий сходство с принципом выстраивания событий во второй части КИ. Как было ранее установлено [Волкова, 1985, 1989: 61-64], главные сюжетные линии в ней, описывающие военные события осады и взятия Казани и моменты «мира», когда царь ведет переговоры с осажденными казанцами, подчинены задаче оправдания Ивана Грозного за пролитую в Казани русскую и татарскую кровь (что было актуально во время написания $К И$, когда начались первые репрессии Ивана Грозного и казни его недавних приближенных). Поэтому в повествовании о взятии Казани последовательно чередуются эпизоды мирных переговоров русских с казанцами с эпизодами военных действий. При этом царь выступает инициатором мирного разрешения осады, а казанцы - 
нежелающими принять предложения Ивана Грозного и призывающими его действовать: «Твори, почто пришел!». Только после получения очередного «жестокого» ответа казанцев на его мирные предложения, подтверждающего их непримиримую позицию, царь отдает приказ о новом штурме Казани.

Исторические ситуации первой части КИ рисуют прямо противоположную картину: если во второй части КИ к миру призывает казанцев Иван Грозный, предлагая им земли на русской территории, то в первой части КИ инициаторами установления мирных отношений между Москвой и Казанью выступают всегда казанцы. Однако в том, как описываются следующие за мирной инициативой казанцев события первой части $К И$, обнаруживается тот же «оправдательный» принцип изображения военной политики московских великих князей: мирная инициатива казанцев, по сюжету КИ, оборачивается их изменой, предательством, убийством ставленников Москвы на казанском престоле. Именно это, по концепции автора, и порождает ответные военные действия московских правителей, всегда идущих навстречу казанцам в их желании урегулировать отношения с Москвой, но вынужденных отвечать на их измены новыми военными походами на Казань. Когда некоторым великим князьям московским не удается сразу отомстить казанцам, эту роль, по сюжету КИ, берет на себя Бог, и виновники измены караются столь явно, что у читателя не остается сомнений: наказание посылается виновнику свыше. Так историческая и провиденциальная сюжетные линии переплетаются уже в начале повествования КИ.

Покажем на нескольких примерах, как работает сюжетный принцип, выявленный на материале последних глав КИ, в первой ее части. Впервые этот принцип обнаруживает себя в рассказах о пленении казанским царем Мамотяком, который, по словам автора КИ, был «от скорпий змий, и ото льва лютаго лютый звърь и кровопийца» (326), великого князя Василия Васильевича, о мести за это его сына великого князя Ивана III, об измене поставленного им на казанское правление царя Махмет-Амина и неудачной попытке сына Ивана III Василия Ивановича отомстить казанцам за измену (главы 11-15). В этом локальном сюжете КИ военные предприятия московских 
великих князей, начиная с Ивана III, рисуются как ответные действия на «великую скорбь», которую наводили казанцы на русских людей, уводя их в плен, сжигая московские посады. Им удалось даже захватить в плен великого князя Василия Васильевича и держать его в Казани как пленника четырнадцать месяцев. Это и послужило, по сюжету КИ, поводом к военным действиям Ивана III, хотевшего отомстить за «безчестие и срамоту отца своего» (328). По рассказу 12-й главы КИ, воеводам Даниилу Холмскому и князю Александру Оболенскому, посланным к Казани с большим войском, удалось пленить самого казанского царя Алехама, что позволило Ивану III посадить на казанском столе одного из служивших ему казанских царевичей - Махмет-Амина, ставшего первым изменником из числа московских ставленников на казанском престоле. Взяв в жены после смерти брата свою невестку, Махмет-Амин подпал под ее влияние, «прелстися от злыя жены своея и послуша проклятаго совъта ея» (330) изменить великому князю и перебить всех русских, живших в Казани. Иван Васильевич, по замечанию автора, не смог отомстить изменнику, так как вскоре умер. Но его сын Василий Иванович начал военные действия против Махмет-Амина, отправив к Казани большое войско во главе с Дмитрием Углицким (глава 14).

В рассказе о ходе и печальном завершении этого похода начала звучать еще одна важная тема КИ, определившая сюжетное решение целого ряда эпизодов о неудачных попытках московских воевод одержать победу над казанцами. Стремясь показать взятие Казани как Богом предопределенную миссию Ивана Грозного и одновременно скомпрометировать князей и воевод - как в его правление, так и в предшествующие эпохи, автор КИ в рассказах о поражении русских войск подчеркивает безответственность русских военачальников, их увлечение «пированиями» во время военных походов, отсутствие необходимой бдительности во время пребывания в землях врагов и упоение быстрыми победами, за которыми следовали трагические поражения. И рассказ о походе на Казань Дмитрия Углицкого прекрасно иллюстрирует эту тенденцию скомпрометировать русских воевод, показав их неспособность взять город и неоправданные потери в рядах русских воинов 
во время военных походов на Казань. Через яркие сюжетные детали и авторские комментарии к ходу событий до читателя доносится мысль о преждевременности попыток русских взять Казань, победа над которой, как будет показано дальше, Богом уготована Ивану Грозному. Русские воеводы терпят жестокое поражение как Божье наказание за недостойное поведение. Так, одержав быструю победу над пировавшими на лугу перед городом казанцами, воеводы, посланные великим князем Василием Ивановичем, прельстились оставшимся от казанского празднества даровым угощением, «начаху ясти без страха и упиватися без воздержания сквернымъ ядениемъ и питием варварским...» (336). В результате выехавшие из города казанцы во главе с царем перебили все русское войско, так что «покры земное лице трупием человеческим, и поле Орское и Царевъ лугъ кровию очервленишася» (336). Таков был первый ответ русских на казанскую измену. Военная месть им не удалась, но возмездие все же настигло изменника Махмет-Амина: как свидетельствует следующая (15-я) глава КИ, «порази его Богъ язвою неизцелною от главы и до ногу его» (338). Интересен с точки зрения сюжетных тенденций и финал этой истории: получив от умирающего и раскаявшегося МахметАмина богатые дары, сын Ивана III Василий Иванович «умилися» и «забы зло его все, и прости его во всемъ» (342). Тема христианского прощения московскими правителями казанцев, даже после всех их злодеяний, проходит через все повествование КИ и завершается рассказом о том, как Иван Грозный пытался остановить своих воинов, избивавших казанцев уже в захваченном городе, когда они раскаялись в своем «жестокосердии» $(522,524)$.

Намеченная в рассмотренных главах сюжетная схема «измена казанцев - военный ответ на нее московских правителей» - прослеживается и в дальнейшем повествовании КИ.

Приведем еще один пример сюжетной реализации выявленной схемы. Это рассказ о первом правлении в Казани Касимовского царя Шигалея (главы 16-20). Здесь повествуется о том, как великий князь Василий Иванович, смягченный покаянием Махмет-Амина, «повъри паки ложной <...> клятве» казанцев и дал им на царство царя Шигалея, находившегося 
у него на службе. Три года тот мирно владел Казанью, но потом казанцы «начаша прелщати царя своего» (342) изменить великому князю. Шигалей не послушал «лукавых» слов казанцев, поэтому они возненавидели его и привели себе из Крыма хана Сахыб-Гирея. Самого же Шигалея отправили назад в Москву. Так свершилась, по версии КИ, очередная измена казанцев, которая повлекла за собой новые попытки великого князя Василия Ивановича отомстить им. Первая оказалась неудачной: во время похода на Казань погибла половина русского войска, переправлявшаяся на ладьях и попавшая в засаду, устроенную казанцами. Сухопутная же рать, одержав победу, не решилась брать приступом Казань, потеряв стенобитные орудия, потонувшие в Волге, и вернулась в Москву. Комментируя такой исход похода, автор КИ пишет, что воеводы напрасно погубили русское войско: «И приидоша к Москвъ со тщетою войска своего, не с радостию, но с печалию великою» (348-350).

Еще большее осуждение заслужили в глазах автора КИ воеводы - участники следующего похода на Казань, который великий князь организовал через шесть лет, не удовлетворившись итогами предшествующего неудачного похода и желая довести дело мести казанцам до конца (глава 19). На этот раз воеводы предприняли попытки штурмовать город и стояли под Казанью целый год. В результате они захватили построенный казанцами острог и могли бы остаться в опустевшей Казани, так как Сафа-Гирей, тогдашний казанский царь, бежал из осажденного города. Но воеводы, возглавлявшие русское войско, по свидетельству КИ, не воспользовались своей победой, ибо никто не решился остаться в Казани. Одной из причин этого, по выражению автора, было то, что «сильнъйши есть злато вой безчисленых»: главный воевода «много себъ злата взя у казанцевъ», поэтому «ни самъ остася в Казани, ни иного же понуди» (354).

В последующих главах КИ показано, что измены казанцев продолжались, вызывая у московских великих князей желание отомстить за эти предательства. Эти повторяющиеся сюжетные ситуации, рисующие взаимоотношения русских и казанцев в военной сфере, перемежаются в КИ с другим материалом, 
касающимся придворного быта московских великих князей, бесчинства князей в период малолетства Ивана Грозного и начала его царствования. Но линия русско-казанских отношений остается главной, стержневой сюжетной линией. Оформляется она таким образом, что виновниками трагических событий предстают, с одной стороны, предатели-казанцы, с другой - корыстные и безответственные русские воеводы, не умеющие и не желающие воспользоваться своей победой над врагом.

Отмеченные нами на материале нескольких глав КИ особенности сюжетного повествования прослеживаются и в других, здесь не рассмотренных главах ее первой части. Затем такое выстраивание сюжета с тремя сюжетными линиями («война», «мир», «Божественный промысел»), подчиняющимися главным идеям автора, переходит и во вторую часть КИ, рассказывающую о победоносном походе Ивана Грозного на Казань. В этой части миротворцами выступают не казанцы, а великий князь московский, многократно предлагавший им сдать город без кровопролития, но каждый раз получавший жесткий отказ принять условия Ивана Грозного.

Таким образом, сюжетная структура первой части КИ оказывается во многом близкой структуре повествования о взятии Казани Иваном Грозным в 1552 г., составляющего вторую часть КИ. И вся «красная» повесть неизвестного автора оказывается подчиненной определенным идеям, раскрывающимся через систему событий и проходящим через весь текст КИ. Исследование сюжетного построения первых 50-ти глав КИ позволило увидеть единый принцип повествования, использованный автором, организующий обширный и разноплановый материал КИ в сюжетное целое.

\section{Примечания}

1 Словарь-указатель сюжетов и мотивов русской литературы. Экспериментальное издание / отв. ред. Е. К. Ромодановская. Новосибирск: Изд-во СО РАН, 2003. Вып. 1. Ред.: М. А. Бологова, Е. К. Никанорова, Е. Н. Проскурина. 243 с.

2 Материалы к Словарю сюжетов и мотивов русской литературы / Институт филологии СО РАН. Новосибирск: Наука, 1996-2012. Вып. 1-10. 
3 Казанская история / подгот. текста и перевод Т. Ф. Волковой, коммент. Т. Ф. Волковой и И. А. Евсеевой // Памятники литературы Древней Руси. Середина XVI в. М.: Худож. лит., 1985. С. 304. Далее ссылки на это издание приводятся в тексте статьи с указанием страницы в круглых скобках.

4 Результаты исследования по выявлению единого принципа сюжетной организации, использованного автором КИ в обеих частях его «красной» повести, также отражены в одной из глав дипломной работы Е. И. Куликовой, выпускницы Сыктывкарского государственного университета им. Питирима Сорокина, «Взаимоотношения Руси и Казанского царства в “Казанской истории”: поэтика сюжета» (Сыктывкар, 2016 г.; науч. рук. Т. Ф. Волкова). Основные наблюдения исследовательницы изложены в тезисах ее доклада на студенческой конференции [Куликова].

\section{Список литературы}

1. Бальбуров Э. А. Нарратив и сюжет как формы осознания времени // Материалы к Словарю сюжетов и мотивов русской литературы. Новосибирск: Сибирский хронограф, 2001. - Вып. 4: Интерпретация текста: Сюжет и мотив. - С. 36-54.

2. Волкова Т. Ф. «Вещный мир» «Казанской истории» // Проблемы изображения материального мира в художественной прозе. - Сыктывкар, 1989. - C. 14-21.

3. Волкова Т. Ф. «Казанская история» и троицкие литературные памятники о взятии Казани. (К вопросу об историко-литературных особенностях «Казанской истории») // ТОДРЛ. - Л.: Наука, 1983. T. 37. - C. 104-117. (a)

4. Волкова Т. Ф. Проблема авторской позиции в историко-публицистическом повествовании XVI в. (на материале сочинений современников о взятии Казани в 1552 г.) // Стиль и идеология. (Активность авторского повествования). - Сыктывкар, 1983. - С. 4-17. (b)

5. Волкова Т. Ф. «Летописец начала царства и великого князя Ивана Васильевича» и троицкие сочинения о взятии Казани как источники текста «Казанской истории» // Древнерусская литература. Источниковедение. - Л.: Наука, 1984. - С. 172-187.

6. Волкова Т. Ф. Работа автора «Казанской истории» над сюжетом повествования об осаде и взятии Казани // ТОДРЛ. — Л.: Наука, 1985. T. $39 .-$ C. $308-322$.

7. Волкова Т. Ф. Словесный портрет в «Казанской истории» // Исследования по древней и новой литературе. - Л.: Наука, 1987. - С. 42-47.

8. Волкова Т. Ф. Развитие повествовательности и художественного вымысла в русской исторической литературе XV-XVII вв.: учеб. пособие по спецкурсу. - Сыктывкар: Сыктывк. гос. ун-т, 1989. - 90 с.

9. Дубровина Л. А. История о Казанском царстве (Казанский летописец): 
списки и классификация текстов. - Киев: Наукова думка, 1989. - 191 с.

10. Дубровина Л. А. Предисловие к изданию 2000 г. // История о Казанском царстве (Полное собрание русских летописей). - М.: Языки русской культуры, 2000. - T. 19. - C. IV-XXVI.

11. Истоки русской беллетристики. Возникновение жанров сюжетного повествования в древнерусской литературе. - Л.: Наука, 1970. - 595 с.

12. Куликова Е. И. Единый принцип сюжетной организации в «Казанской истории» // Слово и текст в культурном и политическом пространстве: материалы Всероссийской научной конференции студентов и аспирантов. Сыктывкар, 13 мая 2016 года. Текстовое научное электронное издание на компакт-диске. - Сыктывкар: Изд-во СГУ им. Питирима Сорокина, 2016. - С. 112-113.

13. Кунцевич Г. 3. История о Казанском царстве, или Казанский летописец. Опыт историко-литературного исследования. - СПб.: Тип. И. Н. Скороходова, 1905. - 515 с.

14. Лурье Я. С. Судьба беллетристики в XVI в. // Истоки русской беллетристики. Возникновение жанров сюжетного повествования в древнерусской литературе. - Л.: Наука, 1970. - С. 420-456.

15. Моисеева Г. Н. Автор «Казанской истории» // ТОДРЛ. - М.; Л.: Изд-во AH CCCP, 1953. - T. 9. - C. 266-290.

16. Моисеева Г. Н. О некоторых источниках «Казанской истории» // ТОДРЛ. - М.; Л.: Изд-во АН СССР, 1955. - Т. 11. - С. 187-198.

17. Орлов А. С. Хронограф и «Повесть о Казанском царстве» // Сборник статей в честь акад. А. И. Соболевского. - Л., 1928. - С. 188-193.

18. Трофимова Н. В. Своеобразие поэтики и функционирования плачей в «Казанской истории» // Вестник славянских культур. - 2016. № 1 (39). - С. 84-92.

19. Тюпа В. И. Нарратология в системе литературоведческого знания // Нарративные традиции славянских литератур (Средневековье и Новое время): сб. науч. тр. / Российская академия наук. Сибирск. отд. Ин-т филологии; отв. ред. Е. К. Ромодановская, И. В. Силантьев. - Новосибирск: Изд-во Новосиб. гос. ун-та, 2007. - С. 5-15.

20. Шмид В. Нарратология. - 2-е изд., испр. и доп. - М.: Языки славянской культуры, 2008. - 304 с. 
Tatyana F. Volkova

(Syktyvkar, Russian Federation)

volkovatf777@gmail.com

\title{
The Narrative Structure of the "Kazan Chronicle"
}

\begin{abstract}
The article analyses the narrative structure of the first part of the "Kazan Chronicle" (chapters 1-57), an eminent monument of the Old Russian literature of the middle of the 16th century. The unique principle of the narration in the text of the writing is brought to light, i.e. the dependence of three story lines - "war", "peace", the "Divine Providence" — on three main ideas presented in the "Kazan Chronicle": the idea of the historical reasonableness of the incorporation of the Tsardom of Kazan into Russia, of the justification of Ivan the Terrible of the massacre between the Russians and the Kazanians during the siege of Kazan, and of the Russian Prince's exploit supported by the God's will, of the conquest of Kazan in 1552. Based on the example of the number of chapters of the first part of the "Kazan Chronicle", it is shown how the narrative principle chosen by the author - the story about the betrayal by the Kazanians, the vengeance for the insult caused to the Russain governers - manifests itself in the precise artistic material and how it transforms in the second part of the "Kazan Chronicle" telling about the siege and conquest of Kazan by Ivan the Terrible in 1552.
\end{abstract}

Keywords: the Old Russian literature, "Kazan Chronicle", storyline, narratology, historical fiction

About the author: Volkova Tatyana F. - Doctor of Philology, Associate Professor, Professor of the Department of Russian Philology, Pitirim Sorokin Syktyvkar State University (pr. Oktyabr'skiy 55, Syktyvkar, 167001, Russian Federation)

Received: March 11, 2019

Date of publication: September 9, 2019

For citation: Volkova T. F. The Narrative Structure of the "Kazan Chronicle". In: Problemy istoricheskoy poetiki [The Problems of Historical Poetics], 2019, vol. 17, no. 3, pp. 7-24. DOI: 10.15393/j9.art.2019.6141 (In Russ.)

\section{References}

1. Bal'burov E. A. The Narrative and Plot as the Forms of Perception of Time. In: Materialy $k$ Slovaryu syuzhetov $i$ motivov russkoy literatury [Materials for a Dictionary of Plots and Motifs in Russian Literature]. Novosibirsk, Sibirskiy khronograf Publ., 2001, issue 4: The Interpretation of the Text: Plot and Motif, pp. 36-54. (In Russ.)

2. Volkova T. F. The "World of Things" of the "Kazan Chronicle". In: Problemy izobrazheniya material'nogo mira v khudozhestvennoy proze [The Problems 
of the Image of the Material World in Artistic Prose]. Syktyvkar, 1989, pp. 14-21. (In Russ.)

3. Volkova T. F. The "Kazan Chronicle" and Troitsky Literary Monuments About the Siege of Kazan. (On the Historical and Literary Features of the "Kazan Chronicle"). In: Trudy Otdela drevnerusskoy literatury [Proceedings of the Department of Old Russian Literature]. Leningrad, Nauka Publ., 1983, vol. 37, pp. 104-117. (In Russ.) (a)

4. Volkova T. F. The Problem of the Author's Position in the Historical and Journalistic Narrative of the 16th Century (Based on the Works of Contemporaries About the Siege of Kazan in 1552). In: Stil' $i$ ideologiya. (Aktivnost' avtorskogo povestvovaniya) [The Style and Ideology. (The Assertiveness of the Author's Narrative)]. Syktyvkar, 1983, pp. 4-17. (In Russ.) (b)

5. Volkova T. F. "A Chronicler of the Beginning of the Kingdom and of Grand Duke Ivan Vasilyevich" and Troitsky Works on the Siege of Kazan as the Sources of the Text of the "Kazan Chronicle". In: Drevnerusskaya literatura. Istochnikovedenie [Old Russian Literature. Source Studies]. Leningrad, Nauka Publ., 1984, pp. 172-187. (In Russ.)

6. Volkova T. F. The Work of the Author of the "Kazan Chronicle" upon the Plot of the Story About the Siege and Conquest of Kazan. In: Trudy Otdela drevnerusskoy literatury [Proceedings of the Department of Old Russian Literature]. Leningrad, Nauka Publ., 1985, vol. 39, pp. 308-322. (In Russ.)

7. Volkova T. F. A Descriptive Portrait in the "Kazan Chronicle". In: Issledovaniya po drevney i novoy literature [Studies on Ancient and New Literature]. Leningrad, Nauka Publ., 1987, pp. 42-47. (In Russ.)

8. Volkova T. F. Razvitie povestvovatel'nosti i khudozhestvennogo vymysla $v$ russkoy istoricheskoy literature XV-XVII vv. [The Development of the Narrative and Fiction in Russian Historical Literature of the 15th-17th Centuries]. Syktyvkar, Pitirim Sorokin Syktyvkar State University Publ., 1989. 90 p. (In Russ.)

9. Dubrovina L. A. Istoriya o Kazanskom tsarstve (Kazanskiy letopisets): spiski $i$ klassifikatsiya tekstov [History of the Kazan Kingdom (Kazan Chronicler): Lists and Classification of Texts]. Kiev, Naukova dumka Publ., 1989. 191 p. (In Russ.)

10. Dubrovina L. A. Preface to the Edition of 2000 Year. In: Istoriya o Kazanskom tsarstve (Polnoe sobranie russkikh letopisey) [The History of the Tsardom of Kazan (A Complete Collection of Russian Chronicles)]. Moscow, Yazyki russkoy kul'tury Publ., 2000, vol. 19, pp. 4-26. (In Russ.)

11. Istoki russkoy belletristiki. Vozniknovenie zhanrov syuzhetnogo povestvovaniya $v$ drevnerusskoy literature [The Origins of Russian Fiction. The Emergence of Genres of the Storyline Narrative in Old Russian Literature]. Leningrad, Nauka Publ., 1970. 595 p. (In Russ.)

12. Kulikova E. I. The Unified Principle of the Narration Structure in the "Kazan Chronicle". In: Slovo i tekst v kul'turnom i politicheskom prostranstve: materialy Vserossiyskoy nauchnoy konferentsii studentov $i$ aspirantov. 13 maya 2016 goda [The Word and Text in the Cultural and Political Space: Materials of the All-Russian Scientific Conference of Students and Postgraduates. 13 May 
2016]. Syktyvkar, Pitirim Sorokin Syktyvkar State University Publ., 2016, pp. 112-113. (In Russ.)

13. Kuntsevich G. Z. Istoriya o Kazanskom tsarstve ili Kazanskiy letopisets. Opyt istoriko-literaturnogo issledovaniya [The History of the Tsardom of Kazan or the Kazan Chronicler. An Experience of Historical and Literary Research]. St. Petersburg, Tipografiya I. N. Skorokhodova Publ., 1905. 515 p. (In Russ.) 14. Lur'e Ya. S. The Destiny of Fiction in the 16th Century. In: Istoki russkoy belletristiki. Vozniknovenie zhanrov syuzhetnogo povestvovaniya $v$ drevnerusskoy literature [The Origins of Russian Fiction. The Emergence of Genres of the Storyline Narrative in Old Russiant Literature]. Leningrad, Nauka Publ., 1970, pp. 420-456. (In Russ.)

15. Moiseeva G. N. The Author of the "Kazan Chronicle". In: Trudy Otdela drevnerusskoy literatury [Proceedings of the Department of Old Russian Literature]. Moscow, Leningrad, Academy of Sciences of the USSR Publ., 1953, vol. 9, pp. 266-290. (In Russ.)

16. Moiseeva G. N. About Some Sources of the "Kazan Chronicle". In: Trudy Otdela drevnerusskoy literatury [Proceedings of the Department of Old Russian Literature]. Moscow, Leningrad, Academy of Sciences of the USSR Publ., 1955, vol. 11, pp. 187-198. (In Russ.)

17. Orlov A. S. The Chronograph and "The Tale of the Tsardom of Kazan". In: Sbornik statey v chest' akademika A. I. Sobolevskogo [A Collection of Articles in Honor of Academician A. I. Sobolevsky]. Leningrad, 1928, pp. 188-193. (In Russ.)

18. Trofimova N. V. The Originality of the Poetics and Functioning of the Lamentations in the "Kazan Chronicle". In: Vestnik slavyanskikh kul'tur [Bulletin of Slavic Cultures], 2016, no. 1 (39), pp. 84-92. (In Russ.)

19. Tyupa V. I. Narratology in the System of Literary Knowledge. In: Narrativnye traditsii slavyanskikh literatur (Srednevekov'e i Novoe vremya) [The Narrative Traditions of Slavic Literature (Middle Ages and Modern Times)]. Novosibirsk, Novosibirsk State University Publ., 2007, pp. 5-15. (In Russ.)

20.Shmid V. Narratologiya [Narratology]. Moscow, Yazyki slavyanskoy kul'tury Publ., 2008. 304 p. (In Russ.) 